\title{
Armoured Fighting Vehicle Injuries in Peacetime
}

Maj TR Whelan

MB, BChir, RAMC*

Surgical Specialist

British Military Hospital, Hannover, West Germany

SUMMARY: A year-long prospective study of injuries caused by armoured fighting vehicles on exercises in West Germany revealed that 2 soldiers were killed. Another 41 needed hospital admission for treatment of injuries of the lower limb (16), upper limb (15), head (8) and back (2).

Tank loader/signallers were peculiarly susceptible to severe leg injuries, due to the ankle being trapped and twisted by the turret rotating within the hull. Insecure, falling hatch covers accounted for many of the hand, head and back injuries.

Soldiers in training need to be made more aware of these particular hazards. Reduced caution would make injuries such as these more common during armoured warfare, and their statistics should be included in casualty estimates.

\section{Introduction}

Injuries sustained during armoured warfare have been well documented, but there have been only sporadic reports about injuries related to armoured fighting vehicles (AFVs) in peacetime. For this reason, a prospective study was conducted at the British Military Hospital (BMH) Hannover, West Germany, to assess all patients admitted with injuries caused directly by AFVs, during a complete annual cycle of military training.

\section{Methods}

BMH Hannover is suitably located for this study as it receives, directly or indirectly, all the casualties from the British Army of the Rhine's two main armoured training areas, around Hohne/Soltau and Hildesheim. (Any soldier initially admitted to a local Krankenhaus is transferred to the BMH before being returned to duty).

For a one year period 1987-1988, data was obtained about each AFV casualty on admission, and the treatment he received was documented. Mortality details were obtained from Headquarters British Army of the Rhine (Coull - personal communication).

\section{Results}

Two soldiers were killed and 41 required hospital admission for treatment of their injuries. Both deaths occurred at the site of injury. A driver of a Chieftain tank died from asphyxia and drowning when his tank drove into a deep, water-filled depression while moving tactically across country at night. The second was the driver of a tracked reconnaissance vehicle (CVR(T)), which skidded off the road on a bend and struck a tree. He sustained a complete transection of the ascending limb of his aortic arch, associated with large bilateral haemothoraces and a fractured sternum.

Of the 41 casualties, $16(39 \%)$ had principally suffered lower limb injuries, 15 (37\%) upper limb injuries, 8 $(19 \%)$ head injuries, and $2(5 \%)$ back injuries (Tables 1-4). Although abdominal injuries have previously been reported in AFV accidents(1), none occurred during this study. Table 5 shows injuries according to Corps.

*Cambridge Military Hospital, Aldershot, Hants GU11 $2 \mathrm{AN}$
Table 1

Lower Limb Injuries

\begin{tabular}{|c|c|c|c|}
\hline Serial & Vehicle & Injury & Cause \\
\hline 1 & Challenger & \# L tibia & Rotating turret \\
\hline 2 & Challenger & \# R tibia/fibula & Rotating turret \\
\hline 3 & Challenger & \# R tibia/fibula & Rotating turret \\
\hline 4 & Chieftain & \# tibia/fibula & Rotating turret \\
\hline 5 & Chieftain & Bruised R leg & Rotating turret \\
\hline 6 & Challenger & Sprained $\mathrm{R}$ ankle & Rotating turret \\
\hline 7 & Challenger & $\begin{array}{l}\text { Crushed/bruised } \\
\mathrm{R} \text { foot }\end{array}$ & Rotating turret \\
\hline 8 & Chieftain ARV & \# L tibia/fibula & Fascines rolled \\
\hline 9 & Minelayer & $\begin{array}{l}\text { Amputated L } \\
\text { toes } 4,5\end{array}$ & $\begin{array}{l}\text { Plough ran over } \\
\text { boot }\end{array}$ \\
\hline 10 & Minelayer & Amputated toe 3 & $\begin{array}{l}\text { Plough ran over } \\
\text { boot }\end{array}$ \\
\hline 11 & Challenger & $\begin{array}{l}\text { \# L metatarsal } \\
\text { EHL tendon } \\
\text { divided }\end{array}$ & $\begin{array}{l}\text { Crushed under } \\
\text { power pack }\end{array}$ \\
\hline 12 & 432/Landrover & $\begin{array}{l}\text { Torn } \mathrm{R} \text { femoral } \\
\text { vein }\end{array}$ & $\begin{array}{l}\text { Crushed between } \\
\text { vehicles }\end{array}$ \\
\hline 13 & Challenger & $\begin{array}{l}\text { Metal foreign } \\
\text { body L thigh }\end{array}$ & Track changing \\
\hline 14 & Challenger & Twisted L knee & Fall \\
\hline 15 & Challenger & Bruised knee & Road wheel fell \\
\hline 16 & 439 & Bruised knee & $\begin{array}{l}\text { Fell into open } \\
\text { hatch }\end{array}$ \\
\hline
\end{tabular}

Thirty nine of the 41 casualties $(95 \%)$ were Private soldiers or junior non-commissioned officers (JNCO's) Only 2 senior NCO's were injured, and none of the casualties were officers.

Seven severe leg injuries were sustained by loaders/ signallers inside their tanks, due to the same mechanism: a boot being trapped between the ammunition storage bins in the hull and the turret floor as the turret began to rotate. The right leg was more frequently injured than the left. Four fractured tibiae were confirmed by X-ray and these were treated in plaster, or by operative 
fixation. The remaining 3 soldiers' ankles were badly sprained or bruised.

The NCO trapped between a Landrover and an armoured personnel carrier (AFV 432) was admitted with an expanding haematoma in his groin; at operation there was profuse bleeding from a hole in his femoral vein, but this was sutured successfully without the need for a graft.

Two sappers had mine ploughs run over their boots, amputating toes.

Of the 15 upper limb injuries, 13 involved the hand only, and featured crushed or fractured fingers. Seven were caused by falling hatch covers. The left hand was injured on 10 occasions, and the right only twice (one was unrecorded). Three soldiers lost fingers, one following the onset of dry gangrene.

One soldier crushed his forearm between the tank turret roof and the breech of the gun, developed compartment syndrome and suffered necrosis of his

Table 2

\section{Upper Limb Injuries}

\begin{tabular}{|c|c|c|c|}
\hline Serial & Vehicle & Injury & Cause \\
\hline 1 & 432 & $\begin{array}{l}\text { Crushed } R \text { index } \\
\text { tip }\end{array}$ & Falling hatch \\
\hline 2 & 432 & \# $\mathrm{R}$ distal phalanx & Falling hatch \\
\hline 3 & Sultan & $\begin{array}{l}\text { Crushed L finger } \\
\text { tips } \\
\text { Dry gangrene }\end{array}$ & Falling hatch \\
\hline 4 & Stalwart & $\begin{array}{l}\text { Open \# L distal } \\
\text { phalanx }\end{array}$ & Falling hatch \\
\hline 5 & Spartan & $\begin{array}{l}\text { Open \# L middle } \\
\text { phalanx }\end{array}$ & Falling hatch \\
\hline 6 & Chieftain & $\begin{array}{l}\text { Open \# L } \\
\text { phalanges }\end{array}$ & Falling hatch \\
\hline 7 & 432 & $\begin{array}{l}\text { \# L proximal } \\
\text { phalanx }\end{array}$ & Falling hatch \\
\hline 8 & - & $\begin{array}{l}\text { L 4,5 EDL tendon } \\
\text { division }\end{array}$ & $\begin{array}{l}\text { Crushed beneath } \\
\text { power pack }\end{array}$ \\
\hline 9 & Chieftain & $\begin{array}{l}\text { Compartment } \\
\text { syndrome } \\
\text { Necrotic LEDL } \\
\text { tendon }\end{array}$ & $\begin{array}{l}\text { Forearm crushed } \\
\text { between gun and } \\
\text { turret roof }\end{array}$ \\
\hline 10 & Abbott & $\begin{array}{l}\text { Amputated L } \\
\text { distal phalanx } \\
\text { Flexion } \\
\text { contractures }\end{array}$ & $\begin{array}{l}\text { Fingertips crushed } \\
\text { beneath gun barrel }\end{array}$ \\
\hline 11 & 432 & $\begin{array}{l}\text { Amputated L } \\
\text { fingertips } 3,4\end{array}$ & Shut in rear door \\
\hline 12 & Ferret & $\begin{array}{l}\text { Open \# L distal } \\
\text { phalanx } 5\end{array}$ & $\begin{array}{l}\text { Trapped between } \\
2 \text { vehicles }\end{array}$ \\
\hline 13 & CVR/T & $\begin{array}{l}\text { Crush \# L } \\
\text { metacarpal } 5\end{array}$ & Road wheel fell \\
\hline 14 & 432 & \# scaphoid & Fall \\
\hline 15 & 432 & $\begin{array}{l}\text { Bruised R } \\
\text { shoulder }\end{array}$ & Fall \\
\hline
\end{tabular}

extensor digitorum longus tendon, which required grafting.

Five of the 8 head injuries were admitted for observation only. The 2 open skull fractures had cerebrospinal fluid rhinorrhoea; both received antibiotic prophylaxis and healed spontaneously. There were no head injury complications.

Table 3

Head Injuries

\begin{tabular}{clll}
\hline Serial & Vehicle & Injury & Cause \\
\hline 1 & Chieftain & $\begin{array}{l}\text { CSF rhinorrhoea, } \\
\text { open \# } \\
\text { CSF rhinorrhoea, }\end{array}$ & $\begin{array}{l}\text { Struck head in } \\
\text { turret }\end{array}$ \\
2 & 432 & Falling hatch \\
\# nose & $\begin{array}{l}\text { Loss of } \\
\text { consciousness }\end{array}$ & Falling hatch \\
3 & 432 & $\begin{array}{l}\text { Concussion } \\
\text { Periorbital } \\
\text { bruising } \\
\text { Loss of } \\
\text { consciousness } \\
\text { Loss of } \\
\text { consciousness } \\
\text { Burns }\end{array}$ & $\begin{array}{l}\text { Falling hatch } \\
\text { Falling hatch }\end{array}$ \\
6 & 432 & $\begin{array}{l}\text { Struck head on } \\
\text { door }\end{array}$ \\
7 & Challenger & Fall \\
8 & 432 & Scalded with \\
coolant
\end{tabular}

Table 4

Back Injuries

\begin{tabular}{llll}
\hline Serial & Vehicle & Injury & Cause \\
\hline 1 & 432 & $\begin{array}{l}\text { Compression \# } \\
\text { T4 \& 5 vert }\end{array}$ & $\begin{array}{l}\text { Hatch fell on } \\
\text { head }\end{array}$ \\
2 & Chieftain & Bruised back & $\begin{array}{l}\text { Tank skidded off } \\
\text { road }\end{array}$ \\
& & &
\end{tabular}

Table 5

Injuries by Corps

\begin{tabular}{lrrlccc}
\hline & RAC & INF & RE & RA & Others & Total \\
\hline Lower limb & 10 & 1 & 3 & 0 & 2 & 16 \\
Upper limb & 2 & 5 & 2 & 3 & 3 & 15 \\
Head/back & 4 & 5 & 1 & 0 & 0 & 10 \\
Total & 16 & 11 & 6 & 3 & 5 & 41 \\
\hline
\end{tabular}

Key: $\mathrm{RAC}=$ Royal Armoured Corps

INF = Infantry

RE = Royal Engineers

RA = Royal Artillery 


\section{Discussion}

This total number of casualties is not large if one considers the tens of thousands of troops using these training areas during the one year period under study. However, 2 soldiers died and many of the 41 injured required prolonged hospital treatment, whilst their units were deprived of valuable manpower. Young soldiers feature more prominently in these casualty statistics than their preponderance in the field explains. Lack of experience is clearly relevant.

Falling hatches account for many of the upper limb, head and back injuries. Although all soldiers are aware of the risk from hatch covers, they still do not always secure the covers correctly and greater care is needed. Lower limb injuries cause more concern during casualty evacuation and because of the long period of disablement. This study exposes the risk to tank signallers/loaders from trapping their feet between the turret floor and the adjacent ammunition stowage bins in the hull of the tank, as the turret begins to traverse. Making these crewmen properly aware of his hazard should reduce the incidence of such severe leg fractures. Additionally, a suitable procedural amendment could require the tank commander and gunner to warn the signaller/loader whenever they were about to traverse the turret.

This mechanism of injury is not confined to British tanks, and a similar problem has been reported in the American M1 Abrams. Silver(2) describes 5 examples where, once again, the injury was only sustained by the crewman in the loader's position. Damage was always confined to the foot (small bone fractures, ligament sprains, and soft tissue crush injury) and the leg was spared.

The risk of death and injury is omnipresent on peacetime exercises, especially when armoured vehicles are involved. The 2 fatalities in this series were probably unavoidable, but many of the injuries are preventable: the rotating turret and the insecure hatch are particular hazards. In time of armed conflict, reduced caution would lead to many more accidental injuries, and these figures should be included in casualty estimates.

\section{Acknowledgements}

I am grateful to Brig (now Maj Gen) J T Coull QHS $\mathrm{L} / \mathrm{RAMC}$ and Maj M Thorpe RAMC for their help in collating the information for this study, and to Lt $\mathrm{Col} A$ F I Shepherd RAMC for permission to report the patients under his care.

REFERENCES

1. KIRBY N G. Ruptured intestine in armoured personne carrier accidents. J R Army Med Corps 1969; 115: 70-72.

2. SiLVER S M. Tank turret crush injuries of the foot. Milit Me 1987 ; 152: $467-469$.

\section{ACADEMIC ACHIEVEMENTS}

MFPHM

MCh (Dublin)

FFPHM

MRCPsych

MRCP
Major T O Jefferson, RAMC

Lt Col J M Ryan, RAMC

Brig A C Ticehurst, L/RAMC

Captain M Baggaley, RAMC

Captain T Hodgetts, RAMC 